DOI https://doi.org/10.30525/978-9934-26-109-1-20

\title{
КРОХМАЛЬ ПШЕНИЧНИЙ ТА ЙОГО ФІЗИЧНА МОДИФІКАЦІЯ
}

\author{
Хомічак Л. М. \\ доктор технічних наук, професор, \\ член-кореспондент Начіональної академії аграрних наук Украӥни, \\ заступник директора з науково-організащійної роботи \\ Інститут продовольчих ресурсів \\ Національної академії аграрних наук України
}

\section{Кузнєцова I. B.}

доктор сільськогосподарських наук, старший науковий співробітник, заступник завідувача відділу технології иукру,

иукропродуктів та інгредієнтів

Інститут продовольчих ресурсів

Національної академії аграрних наук України

\author{
Висоцька С. I. \\ аспірант, \\ молодший науковий співробітник відділу аграрної економіки \\ і продовольства \\ Національна академія аграрних наук Украӥни \\ м. Київ, Україна
}

Вступ. Відомо, що у різних галузях харчової промисловості значне застосування отримали певні види нативних й модифікованих крохмалів із заданими властивостями. Дослідженням властивостей нативного i модифікованих видів крохмалів присвячені наукові роботи Керра Р.В. [1], Ріхтера М. [2], Трегубова М.М. [3], Андрєєва М.P. [4], Гулюка М.Г. [5], Карпова В.Г. [6], Літвяк В.В. [7], Lim Y.-М. et. al. [8] та інші.

Проте, до теперішнього часу не в повній мірі досліджено особливості і механізми модифікації крохмалю та крохмалевмісної сировини. Третім після кукурудзяного і картопляного, за виробництвом у світі $\epsilon$ крохмаль пшеничний. Завдяки особливостям зерна пшениці, як сировини з виробництва крохмалю, нативний крохмаль $\epsilon$ відмінним за властивостями від кукурудзяного і картопляного. Відповідно, зерна 84 
пшеничного крохмалю дрібніші за зерна картопляного і кукурудзяного крохмалів, мають круглу або еліптичну форму. Пшеничний крохмаль містить переважно круглі (20-35 мкм) і дрібні (2-10 мкм) зерна. Температура клейстеризації пшеничного крохмалю $58-61^{\circ} \mathrm{C}$.

Крохмаль пшеничний утворює клейстер невисокої в'язкості та більш прозорий порівняно з кукурудзяним клейстером. За високих концентраціях крохмальної суспенії виявляє здатність до утворення еластичного гелю. $€$ поширеним у застосуванні в кондитерській i хлібопекарській промисловості.

Отже, вивчення фізико-хімічних і функціональних властивостей крохмалю пшеничного і його фізичної модифікації $\epsilon$ актуальною проблемою для харчової промисловості.

Мета роботи: вивчити фізико-хімічні та функціональні властивості пшеничного крохмалю нативного та фізичномодифікованого.

Методи та методики досліджень. Об'єктом дослідження були крохмаль пшеничний нативний (виробник Viresol, Угорщина), крохмаль пшеничний фізичномодифікований, борошно модифіковане пшеничне.

Підготовка дослідних зразків. Здійснювали фізичну модифікацію зразків крохмалю та борошна пшеничного. Модифікацію зразків здійснювали шляхом підготовки їх способом заварювання, з наступним сушінням в конвективній сушарці за температури $110-120^{\circ} \mathrm{C}$ впродовж $30-45$ хв та за температури до $60-65^{\circ} \mathrm{C}$ до отримання продукту - борошно модифіковане із вмістом сухих речовин 6-10\%, подрібненням та просіюванням.

Методики досліджень. Дослідження фізико-хімічних показників зразків здійснювали за допомогою загальноприйнятих стандартизованих методик, а саме вміст: гігроскопічної води - прискореним методом [9], $\mathrm{pH}$ [10], титруєма кислотність (К) - методом титрування [10], золи методом озолення без прискорювача [9], вміст амілози (А) за Ріхтером М. [1], адсорбційну здатність - за удосконаленою методикою 3 індикатором метиленовим блакитним [11].

Результати досліджень. В розвитку уявлень щодо перетворень крохмалю під дією модифікації провідне місце має порівняння фізикохімічних властивостей крохмалю нативного та його модифікацій в нативному стані та в сировині. Це дозволяє більш повно визначити зміни , що відбуваються як із самою крохмальною гранулою так i з іншими компонентами за модифікації крохмалевмісної сировини. Порівняльні показники якості представлено в табл. 1. 
Таблиця 1

Якість крохмалю пшеничного нативного та модифікованого

\begin{tabular}{|l|c|c|c|c|c|}
\hline \multicolumn{1}{|c|}{ Найменування } & $\mathbf{W , \%}$ & $\mathbf{p H}$ & $\mathbf{K , \mathbf { c m } ^ { 3 }}$ & $\mathbf{3 о л а , \% ~}$ & $\mathbf{A , \%}$ \\
\hline Крохмаль нативний & 8,43 & 6,23 & 18,50 & 0,23 & 20,43 \\
\hline $\begin{array}{l}\text { Крохмаль фізично- } \\
\text { модифікований }\end{array}$ & 8,99 & 6,25 & 16,48 & 0,20 & 26,54 \\
\hline $\begin{array}{l}\text { Борошно модифіковане } \\
\text { пшеничне }\end{array}$ & 10,54 & 6,26 & 9,4 & 1,78 & 26,02 \\
\hline
\end{tabular}

Відзначено, що після фізичної модифікації знизився показник кислотності (К) крохмалю на 2 од., що вказує на зниження вмісту органічних кислот внаслідок теплового оброблення. Отже, має значний вПлив компонентний склад, оскільки вміст органічних кислот значно знизився за модифікації сировини (борошна). Водночас відбулись зміни в структурі крохмальній гранулі, адже показник вмісту амілози (А) збільшився на 6 од. Враховуючи, що крохмаль пшеничний на 84,2\% складається 3 дрібних крохмальних гранул, то зростання лінійної частини крохмалю має достатньо високий показник. Слід врахувати, що коефіцієнт модифікації для крохмалю пшеничного становить 0,784 [7]. За такого коефіцієнту модифікації ступінь кристалічності зростає з 36,4\% до 47,2\%, що відповідно сприяє застосуванню такого крохмалю для виробництва хліба з подовженим терміном зберігання. Отже, зв'язана волога 3 крохмальною гранулою може використовуватись як вологопоглинальний компонент.

Відомо, що одним з показників функціональної здатності $\epsilon$ сорбційна ємність за метиленовим блакитним. Молекули індикатора метиленового блакитного адсорбуються на порах площею 0,78-1,3 нм². Індикатор метиленовий блакитний - це молекула багатогранник, яка не проникає всередину мікро- і мезопор.

Модифіковані крохмалепродукти, характеризуються розвиненішою поверхнею ефективного радіусу пір, що дозволяє їм накопичувати в своїй структурі більше води та сприятливо впливати на протікання ферментативних іонообмінних i інших реакцій в шлунково-кишковому тракті. Збільшена сорбція індикатора, модифікованих крохмалепродуктів, як відомо корелює з сорбцією ними мікроорганізмів, зокрема, E. coli. Отже, адсорбція метиленового блакитного залежить від питомої поверхні часток гранул. Результати досліджень представлено в таблиці 2. 
Таблиця 2

Сорбційна смність зразків крохмалю пшеничного нативного та модифікованого, включаючи модифіковане в сировині $(\mathbf{n}=3, \mathbf{p} \leq \mathbf{0 . 0 5})$

\begin{tabular}{|c|c|c|c|}
\hline \multirow{2}{*}{$\begin{array}{c}\text { No } \\
\text { п/п }\end{array}$} & \multirow{2}{*}{ Найменування } & \multicolumn{2}{|c|}{ Сорбційна ємність борошна, мг/г } \\
\cline { 3 - 4 } & & нативне & модифіковане \\
\hline 1 & Крохмаль пшеничний & 46,42 & 109,61 \\
\hline 2 & Борошно пшеничне & 49,37 & 119,64 \\
\hline
\end{tabular}

Відмічено, що проведення фізичної модифікації сприяє зростанню сорбційної ємності як для крохмалю в нативному так і в сировині. Отже, теплова обробка змінює структуру компонентів, що сприяє підвищенню сорбційної ємності продукту.

Висновки. Вивчено фізико-хімічні показники пшеничного крохмалю та показано вплив фізичної модифікації на зміну структури крохмальних гранул. Визначено сорбційну ємність як складову функціональності продукту та показано, що за модифікації крохмалепродукти, характеризуються розвиненішою поверхнею ефективного радіусу пор, що дозволяє їм накопичувати в своїй структурі більше води та сприятливо впливати на протікання ферментативних іонообмінних і інших реакцій.

\section{Література:}

1. Керр Р.В., Цезар Ж.В., Кристенсен Л.М. и др. Химия и технология крахмала / под ред. Р.В. Керр. пер. с англ. Москва: Пищепромиздат, 1956. $579 \mathrm{c}$.

2. Рихтер М., Аугустат 3, Ширбаум Ф. Избранные методы исследования крахмала. пер. с немец. Москва: Пищ. пром-сть, 1975. $182 \mathrm{c}$.

3. Трегубов Н.Н., Жарова Е.Я., Жушман А.И., Сидорова Е.К. Технология крахмала и крахмалопродуктов. Москва: Легкая и пищ. пром-сть, $1981.421 \mathrm{c}$.

4. Андреев Н.Р. Основы производства нативных крахмалов. Москва: Пищепромиздат, 2001. 289 с.

5. Гулюк, Н.Г., Жушман А.И., Ладур Т.А., Штыркова Е.А. Крахмал и крахмалопродукты. Москва: Агропромиздат, 1985. 240 с.

6. Карпов В.Г. Разработка технологии новых видов крахмалопродуктов экструзионным способом: автореф. дис.... д-ра техн. наук: 05.18.05. «Технология сахара и сахаристых продуктов, чая, 
табака и субтропических культур» / Bсерос. науч.-исслед. ин-т крахмалопродуктов. Москва, 2000. 48 с.

7. Литвяк В.В., Ловкис 3.В. Фундаментальные и прикладные исследования крахмала и крахмалопродуктов. Труды БГУ. 2014. Том 9, часть 2. С. 152-163.

8. Lim Y.-M., Hoobin P., Ying D., Burgar I. et al. Physical characterisation of high amylose maize starch and acylated high amylose maize starches. Carbohydrate polymers. 2015. V. 117. P. 279-285.

9. Методика проведення кваліфікаційної експертизи сортів рослин на придатність до поширення в Україні. Методи визначення показників якості продукції рослинництва. Український інститут експертизи сортів рослин. $158 \mathrm{c}$.

10. ДСТУ 4380:2005. Крохмаль модифікований. Загальні технічні умови. Держспоживстандарт України. Київ, 2006. 20 с.

11. Методичні рекомендації 3 визначення сорбційної ємності (знебарвлюючої здатності) модифікованих крохмалепродуктів за органічним барвником метиленовим блакитним / Л.М. Хомічак, I.В. Кузнєцова, С.В. Ткаченко, С.І. Висоцька, М.А. Ярмолюк. Київ, 2020. 13 с. 